\section{Fears for oldest human footprints}

Threats to the world's oldest hominid footprints in Tanzania are again stirring debate over how to best protect the 3.7-million-yearold tracks.

Discovered by Mary Leakey's team in 1978, the 23-metre-long track of footprints at an isolated site called Laetoli were in 1995 covered with an elaborate protective layer after they began to deteriorate with exposure. Now weathering has begun to undermine those protections, raising concerns that the prints preserved in a volcanic ash bed could be harmed by erosion, livestock or humans.

It has prompted Tanzanian anthropolo-

gist, Charles Musiba, now at the University of Colorado in Denver, to call for the creation of a new museum to reveal and display the historic prints. But other anthropologists question this idea - as they did when the tracks were covered - because Laetoli is several hours' drive into Ngorongoro National Park, making guarding and maintaining any facility extremely difficult. Musiba presented his proposal for the museum last month at the International Symposium on the Conservation and Application of Hominid Footprints, in South Korea. He says that Tanzania now has the scientific capacity and the funds to construct and monitor a museum.

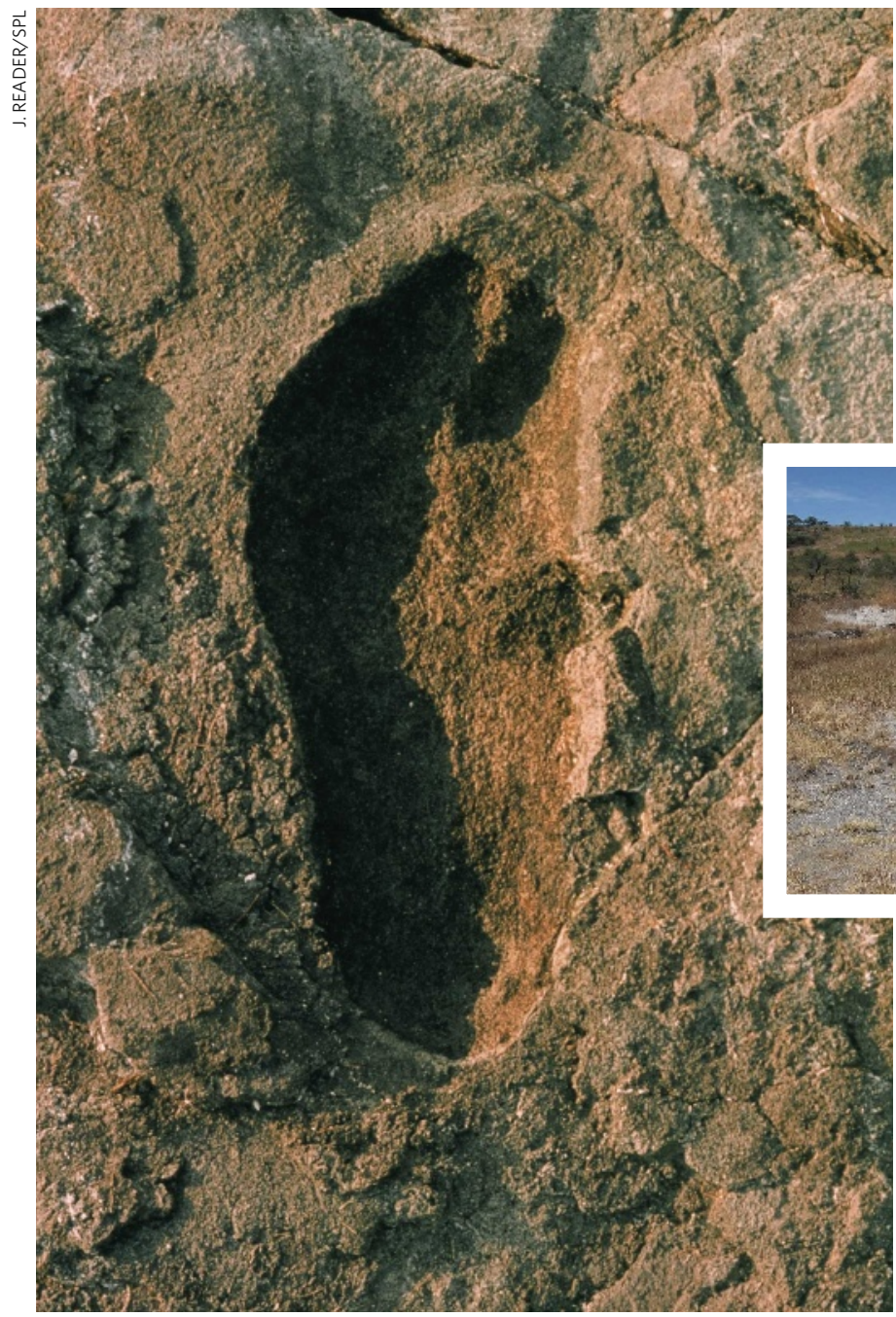

Vegetation threatens to erode the trail of fossilized footprints at Laetoli in the Ngorongoro National Park, Tanzania.

"I feel compelled to bring this issue out," says Musiba. "The current conditions show the protections are temporary. A fully fledged museum could be part of a walking safari trail for tourists."

But this concept worries other researchers such as anthropologists Tim White of the University of California, Berkeley, and Terry Harrison at New York University. They are among a group that favours cutting the entire track out of the hillside, then installing it in a museum in a Tanzanian city, either Dar es Salaam or Arusha. "If they are uncovered, they will be a magnet for trouble," says White. "Then the prints will be worn away."

Donatius Kamamba, who is head of the National Museum in Dar es Salaam and also director of the Tanzanian Department of Antiquities - the agency responsible for the Laetoli footprint site - expressed surprise over the erosion report and the museum proposal. He says that his agency will investigate the site, but he questions the feasibility of moving an ash bed that could potentially crumble apart.

The protective layer now in place was constructed by specialists from the Getty Conservation Institute in Los Angeles. A layer of dirt had been placed over the footprints by researchers such as Leakey and White. But acacia seeds weren't sifted out of the soil, so trees started growing, threatening to tear apart the layer of hardened volcanic ash. Getty conservationists Neville Agnew and Martha Demas removed the old layer and growth, covered the prints with a special fabric mat designed to limit water intrusion, then covered this with cleaned soil and rocks. This worked well until the past couple of years, when increased rains filled the surrounding run-off ditches with silt, leading to erosion exposing the mat's edges. All agree that the mat needs to be covered swiftly, in case, for example, local tribespeople attempt to remove it for other uses. But a long-term solution is still up for debate.

The National Museum is currently undergoing an expansion. Harrison thinks Tanzania would be wise to consider putting the footprints there. But archaeologist Audax Mabulla, of the University of Dar es Salaam, favours Musiba’s suggestion. "We should open a small section of the footprints in an environmentally friendly building," says Mabulla. "Then people can have access and appreciate them."

Whatever happens, concerns are mounting about immediate improvements because the rainy season is already under way.

Rex Dalton 